\title{
The impact of technology on economic growth: some new ideas and empirical considerations
}

Citation for published version (APA):

van Loo, I., \& Soete, L. L. G. (1999). The impact of technology on economic growth: some new ideas and empirical considerations. MERIT, Maastricht Economic Research Institute on Innovation and Technology. MERIT Research Memoranda No. 017 https://doi.org/10.26481/umamer.1999017

Document status and date:

Published: 01/01/1999

DOI:

10.26481/umamer.1999017

Document Version:

Publisher's PDF, also known as Version of record

\section{Please check the document version of this publication:}

- A submitted manuscript is the version of the article upon submission and before peer-review. There can be important differences between the submitted version and the official published version of record.

People interested in the research are advised to contact the author for the final version of the publication, or visit the DOI to the publisher's website.

- The final author version and the galley proof are versions of the publication after peer review.

- The final published version features the final layout of the paper including the volume, issue and page numbers.

Link to publication

\footnotetext{
General rights Owners
rights.

- You may freely distribute the URL identifying the publication in the public portal. please follow below link for the End User Agreement:

www.umlib.nl/taverne-license

Take down policy

If you believe that this document breaches copyright please contact us at:

repository@maastrichtuniversity.nl

providing details and we will investigate your claim.
}

Copyright and moral rights for the publications made accessible in the public portal are retained by the authors and/or other copyright owners and it is a condition of accessing publications that users recognise and abide by the legal requirements associated with these

- Users may download and print one copy of any publication from the public portal for the purpose of private study or research.

- You may not further distribute the material or use it for any profit-making activity or commercial gain

If the publication is distributed under the terms of Article $25 \mathrm{fa}$ of the Dutch Copyright Act, indicated by the "Taverne" license above, 


\title{
The Impact of Technology on Economic Growth: Some New Ideas and Empirical Considerations*
}

\author{
Ivo De Loo \\ Statistics Netherlands, Heerlen \\ Luc Soete \\ MERIT, Maastricht University
}

April 1999

\begin{abstract}
R\&D based models relating technical change and economic growth have been unsuccessful in explaining the recent productivity paradox: R\&D efforts have risen continuously in advanced countries during the postwar period whereas productivity growth has, if anything, declined. Several explanations of the paradox are offered, together with empirical ways of testing them. The notion that $R \& D$ efforts are more and more attributed to product differentiation, thus enlarging consumers' welfare while simultaneously exhibiting only limited effects on economic growth, looks very promising in explaining the productivity paradox.
\end{abstract}

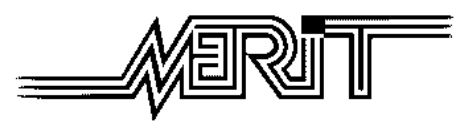

Maastricht Economic Research Institute on Innovation and Technology, University of Maastricht, P.O. Box 616, 6200 MD Maastricht, The Netherlands, tel: +31 43 3883891, fax: +31 43 3216518, Email: luc.soete@algec.unimaas.nl. Ivo De Loo can be reached at Statistics Netherlands, Kloosterweg 1, 6412 CN Heerlen, The Netherlands, tel: +3145 5706756, fax: +31 45 5706279, Email: idlo@cbs.nl.

\footnotetext{
The authors wish to thank Thomas Ziesemer for his comments. The usual disclaimer applies.
} 


\section{Introduction}

The relationship between technology and economic growth has been captured in a vast number of formal models for almost half a century. Early neoclassical models like Solow (1956) treated technical change as an exogenous variable, illustrating how long-run economic growth only depended on (exogenous) technical change. Arrow (1962), who endogenized technology by assuming learning by doing, stated that it grew at a constant rate, and found that long-run economic growth crucially depends on population growth. Other important contributions in the 1960s were made by Uzawa (1965), Phelps (1966), Conlisk $(1967,1969)$ and Shell (1967) among others, who all related technology growth to some specification based on labour resources devoted to the development of new technologies and ideas. On the other hand, the more recent type of models of the endogenous growth literature by Romer (1990), Grossman and Helpman (1991a, 1991b) and Aghion and Howitt (1992) all share the characteristic that a continued increase in the level of resources spent on the creation of new technologies leads to a continued increase in economic growth. Jones (1995a, 1995b) holds an impassioned debate hereagainst, for the number of scientists engaged in $\mathrm{R} \& \mathrm{D}$ (which is generally believed to be an acceptable proxy of the state of technology) in advanced countries rose substantially over the last 40 years, while economic growth hardly rose at all during that period. Although Jones' focus is mainly on the US, we would reach similar conclusions when analyzing the situation for European countries ${ }^{1}$.

Jones (1995a) gives several explanations for the contrasting relationship between the state of technology and productivity growth, known in the literature as the productivity paradox. These explanations are partially inspired by an article written by Romer (1987). They are that either some offsetting effect occurs in the movement of other variables that permanently affect economic growth, or that persistent changes in policy measures which should have permanent effects on economic growth, in fact do not. After a lengthy empirical analysis Jones concludes that these explanations cannot be endorsed and that endogenous growth models are therefore inconsistent with time series evidence.

The question remains whether an attractive alternative explanation of the productivity paradox can be found. And if so, can we say something about its empiric validity, and point out a way of testing it? We will try to answer these questions in the remainder of this paper, without resorting to formal modeling per se. It is merely our intention to set out our main ideas and their justification. Further (mathematical) elaborations will be left for future research. Therefore, Section 2 introduces an interesting alternative explanation of the productivity paradox, namely by examining

1 The data and graphs that show so can be obtained from the authors upon request. For a more detailed overview of the theories on technology and economic growth that have been issued over the years, the interested reader is referred to Schneider and Ziesemer (1996). 
shifts in the nature of $R \& D$ efforts ${ }^{2}$. Then, Section 3 attempts to sustain this explanation by means of two sets of economic indicators. Finally, Section 4 summarizes.

\section{Shifts in the Nature of R\&D efforts}

An appealing alternative explanation of the productivity paradox, which is unfortunately not considered by Jones (1995a, 1995b), is to look at possible shifts in the nature of $R \& D$ efforts in relation to productivity growth. In discussing the productivity paradox from this perspective, three explanations arise. These explanations are:

1. R\&D statistics (particularly in small firms) seem to capture only a part, and sometimes even less than half of the total efforts attributed to technical progress, which does not show up in official statistics (OECD 1992);

2 . The nature of new technologies has changed in such a way that nowadays both complementary technologies have to be developed and radical organizational changes have to be made in order to gain a technology's full potential (David 1990);

3. R\&D efforts may have become more and more devoted to product differentiation than to (product or) process innovation, thus hardly affecting economic growth but more so total consumers' welfare (Soete 1996 and Young 1998).

Testing for the applicability of these notions in a formal way is quite a challenge (and Young 1998 has already partially done so). A model that may prove very suitable is a specification à la Jones (1995b), which is enlarged by Quah and Keely (1998) and Jones and Williams $(1998)^{3}$. Here however, we will continue by pointing out which explanation of the above we find most attractive in explaining the productivity paradox, while trying to assess its importance by means of several economic indicators ${ }^{4}$.

\footnotetext{
2 Other possible explanations look at the productivity paradox across countries and between sectors. Across countries, fragmentation aspects play an important role for even when taken together, the individual R\&D efforts of European countries (with a limited size) are simply not comparable to those of the US. Between sectors, there can be structural differences between the moment in time when innovations are put into use and the moment that the fruits of them can be obtained. Especially within ICT sectors this time gap can be large. These structural differences would indicate an aggregation problem across sectors, as stated by Foster, Haltiwanger and Krizan (1998).
}

3 Using such a model would not only allow us to validate our explanations of the productivity paradox further, but also give us the opportunity to discuss, for example, balanced growth issues.

4 The other explanations, including those of footnote 2 , have been discussed more prominently in the recent literature anyway. 


\section{Evaluation}

Both the investment strategies of firms and of consumers will change if the economic situation changes, as indicated by for example Kurdas (1994). A normal scenario would be that in times of economic booms, firms and customers spend large amounts of money on a similarly large variety of products. In times of recessions the reverse situation takes place: the real interest rate goes up, and people will spend their money on a rather fixed set of goods and services (although slight variations in the nature of the goods and services are possible), while firms postpone their most risky $R \& D$ efforts and invest in variations on existing products in order to fulfill consumers' demands. Besides, they might consider financing their R\&D efforts more and more by themselves, instead of speculating on financial markets. If this way of reasoning is in line with economic practice, then there should be a relationship between the amount of money spent on $R \& D$ and the real interest rate. As it turns out, $R \& D$ growth and the growth of the real interest rate have moved together over the last 25 years quite closely (although the strength of the relationship has weakened considerably from the late 1980s onwards) ${ }^{5}$. Thus we may say that as an economic downswing sets in, people will invest in less risky projects. For a firm, trying to achieve maximal profits, this could imply a preference for emphasizing equivalent innovations over non-equivalent innovations. Thus, economic growth would not be increased but consumers' welfare would (Young 1998). It is very interesting that this particular role of the real interest rate has never been considered much in formal modeling (exceptions perhaps being McKinnon 1973, Morrison and Berndt 1981, Shaw 1973 and Fry 1988).

Equivalent innovations as well as non-equivalent innovations utilize $R \& D$, but the latter type of innovation is probably patented more heavily by default. This means that analyzing the ratio of patents granted by the US Patent Office (USPTO) and total R\&D expenditures (in constant prices) can test the aforementioned notion. The ratio is standardized so that it equals 1 in 1985. For reasons of data availability, we focus on total manufacturing (ISIC code 30) only. Figure 3.1 contains the relevant statistics. The countries considered are the G7, Japan, the Netherlands, the US, Germany, France and the UK.

5 Again, graphs and regression analyses that show so can be obtained from the authors upon request. 
PATENTS GRANTED PER UNIT R\&D

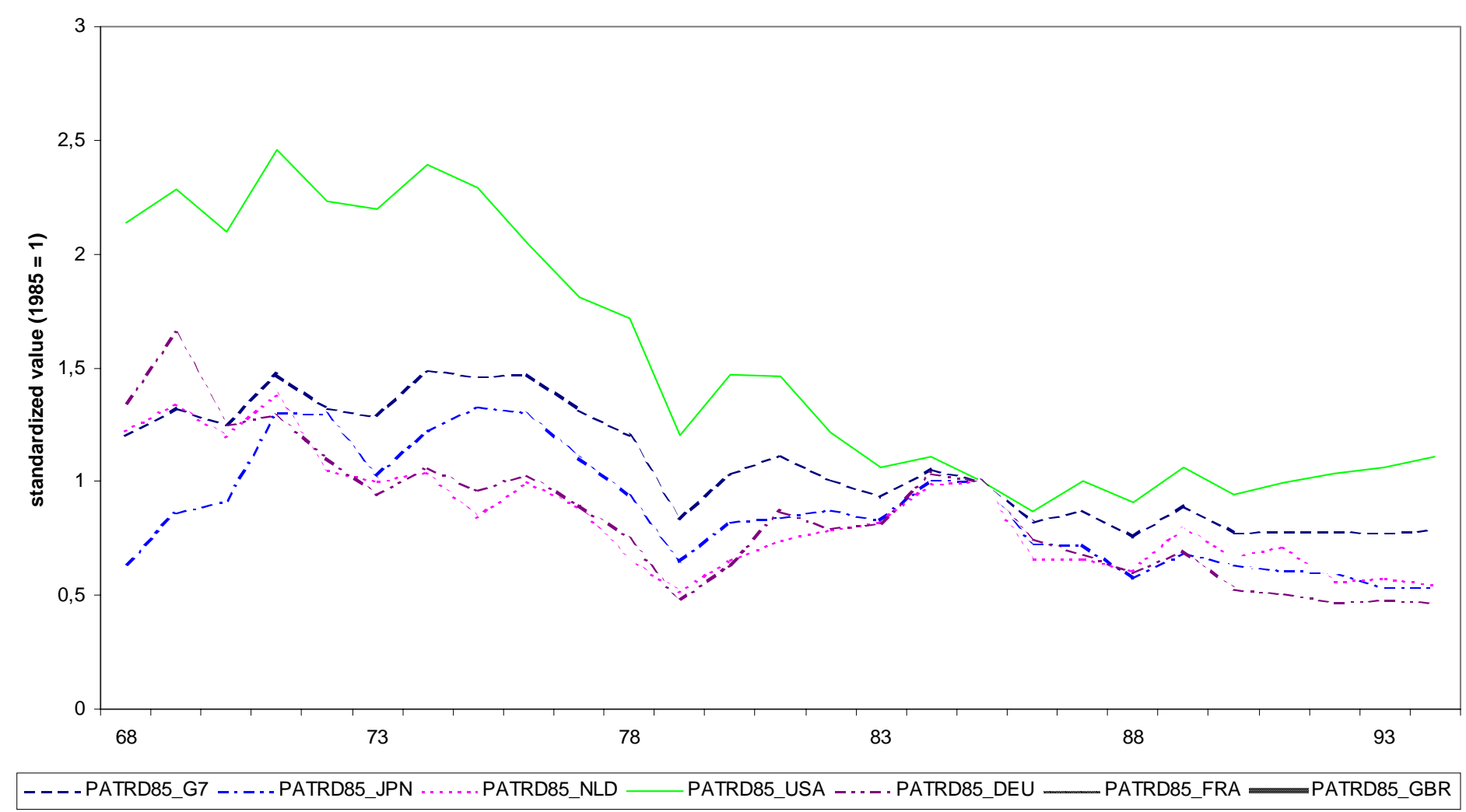

Figure 3.1 Standardized value of the ratio between patents granted by the USPTO and deflated R\&D expenditures for several countries between 1968-1994 (1985 = 1). Source: USPTO, ANBERD and UNIDO databases. 
There should be a downfall (or at least a stagnation) in the ratio of patents granted per unit R\&D over time if firms indeed have switched their R\&D efforts from nonequivalent to equivalent innovations, especially since the mid 1980s. Figure 3.1 obviously sustains this: the ratio has decreased steadily over the years. There appears to be a rise in the ratio of the US and (to a lesser extent) the G7 at the end of the sample period though, which is probably induced by the general resurgence of Western economies that occurred around that time ${ }^{6}$. However, as Griliches (1989) points out, the general decline in patenting since the 1970s is at least partly attributable to budgetary and inefficiency cycles faced by the USPTO itself (which could create lags between the time a patent is actually applied for and the moment it is being granted. Unfortunately, long time series on patent applications were not at our disposal). Besides, Figure 3.1 does not touch upon the issue that past R\&D expenditures may have an influence on current patenting (Pakes 1985), which would certainly affect the trends shown in the graph. Thus the ideas expressed above can be said to be, in a way, overstated in importance. Nevertheless, their relevancy and empirical validity still remains, and we can try to endorse them by another indicator.

If people indeed started to invest in less riskier projects over the years, we would expect the business financed part of business $R \& D$ expenditures (that can be associated with equivalent innovations) to grow more rapidly than its non-business financed counterpart and government, military and higher education R\&D taken together (which are generally associated with non-equivalent innovations). If we calculate this ratio for total manufacturing and check whether on average, it has been increasing over time, we find that the evidence indeed points into this direction. Table 3.1 summarizes the results. We consider three time periods: 1968-1994, 19681984 and 1985-1994. Furthermore, the same countries as in Figure 3.1 are analyzed. The extremely large values for Japan, and to a lesser extent, Germany across all periods may indicate that these countries switched from non-equivalent to equivalent innovations a long time ago already. Especially Japan seems to have increased its equivalent innovations rapidly over time. Yet, as stated, this is a trend that can be seen in all countries when moving from the 1960s and 1970s to the 1980s and 1990s, so that the conclusions reached above are endorsed. Of course, this trend should be coupled with the movement from negative to positive real interest rates that occurred around the mid 1980s for almost all the countries below.

6 Although the USPTO data are obviously biased against the US. 
Table 3.1 Mean ratio of the business financed part of business R\&D and all other R\&D expenditures in several countries for three time periods. Source: BERD, GERD and ANBERD databases.

\begin{tabular}{|llll|}
\hline & Time period & & \\
Gountry & $\mathbf{1 9 6 8 - 1 9 9 4}$ & $\mathbf{1 9 6 8 - 1 9 8 4}$ & $\mathbf{1 9 8 5 - 1 9 9 4}$ \\
Japan & .826 & .712 & 1.018 \\
Netherlands & 1.358 & 1.167 & 1.683 \\
US & .846 & .809 & .909 \\
Germany & .784 & .725 & .884 \\
France & 1.233 & 1.105 & 1.453 \\
UK & .610 & .598 & .630 \\
\hline
\end{tabular}

Looking at the overall results, there appears to be a convincing amount of evidence to endorse the explanation of the production paradox given in section $2: \mathrm{R} \& \mathrm{D}$ has become more and more devoted to product differentiation than to (product or) process innovation, thus hardly affecting economic growth but more so total consumers' welfare. The next step would be testing the explanation further by embedding it into a formal, empirically testable economic model ${ }^{7}$. In doing so, the real interest rate should be explicitly taken along ${ }^{8}$. However, this will have to remain a point for further study.

\section{Conclusions}

$\mathrm{R} \& \mathrm{D}$ based models relating technical change and economic growth have been unsuccessful in explaining the recent productivity paradox: R\&D efforts have risen continuously in advanced countries during the postwar period whereas productivity growth has, if anything, declined. We offer three explanations of the paradox, and

7 Young (1998) has already introduced such a formal model, but it is hard to test with real-life data.

8 It is not clear however that the interest rate itself should enter the model, because of a number of practical problems that would occur (since the first-order conditions under cost minimization already contain interest charges). There is an attractive economic interpretation of the foregoing relationship though, which would circumvent some of these problems. In it, the capacity utilization rate plays an important role. In times of economic upswings, both labour productivity and the capacity utilization rate rise. When the upswing is reaching its upper level, people generally fear that inflation will set in and that the Central Bank will therefore raise interest rates (linked with the shifts in nature of R\&D efforts mentioned in the main text). When the Central Bank indeed does so, capacity utilization drops and economic activity falls. Over time, the economy will go through a downswing where the reverse situation happens. Thus in the model there should be a relationship between labour productivity growth and the capacity utilization rate on the one hand (which is quite common), and R\&D expenditures and the real interest rate on the other (which is new). 
consider one of them empirically. The notion that R\&D efforts are more and more attributed to product differentiation, thus enlarging consumers' welfare while simultaneously exhibiting only limited effects on economic growth, may very well be the most promising in explaining the productivity paradox. Besides, we find an interesting relationship between $R \& D$ growth and the growth of the real interest rate in our dataset of advanced countries, which poses great challenges for formal modeling. 


\section{References}

Aghion, P. and Howitt, H., 'A Model of Growth through Creative Destruction', Econometrica 60 (1992), pp. 323-351.

Arrow, K., 'The Economic Implications of Learning by Doing', Economic Studies 29 (1962), pp. 155-173.

Conlisk, J., 'A Modified Neoclassical Growth Model with Endogenous Technical Change', The Southern Economic Journal 34 (1967), pp. 199-208.

'A Neoclassical Growth Model with Endogenously Positioned Technical Change Frontiers', Economic Journal 79 (1969), pp. 348-362.

David, P.A., 'The Dynamo and the Computer: An Historical Perspective on the Modern Productivity Paradox', American Economic Review 80 (1990), pp. 355-361.

Foster, L., Haltiwanger, J. and Krizan, C.J., 'Aggregate Productivity Growth: Lessons from Microeconomic Evidence', NBER Working Paper 6803 (1998).

Fry, M.J., 'Money, Interest, and Banking in Economic Development', John Hopkins University Press, Baltimore, 1988.

Griliches, Z., 'Patents: Recent Trends and Puzzles', NBER Working Paper 2922 (1989).

Grossman, G.M. and Helpman, E., Innovation and Growth in the Global Economy, MIT Press, Cambridge, 1991 (a). 43-61 (b)

, 'Quality Ladders in the Theory of Growth', Review of Economic Studies 58 (1991), pp.

Jones, C.I., 'Time Series Tests of Endogenous Growth Models', Quarterly Journal of Economics 110 (1995), pp. 495-525 (a).

, 'R\&D-Based Models of Economic Growth', Journal of Political Economy 103 (1995), pp. $759-784$ (b).

Jones, C.I. and Williams, J.C., 'Measuring the Social Return to R\&D', Quarterly Journal of Economics 113 (1998), pp. 1119-1135.

Kurdas, C., 'Theories of Technical Change and Investment: Riches and Rationality', St. Martin's Press, New York, 1994.

McKinnon, R.L., Money and Capital in Economic Development, Brookings Institution, Washington, 1973

Morrison, C.J. and Berndt, E.R., 'Short-Run Labor Productivity in a Dynamic Model', Journal of Econometrics 16 (1981), pp. 339-365. 
OECD, Technology and the Economy: the Key Relationships, OECD, Paris, 1992.

Pakes, A., 'On Patents, R\&D and the Stock Market Rate of Return', Journal of Political Economy 93 (1985), pp. 390-409.

Phelps, E.S., 'Models of Technical Progress and the Golden Rule of Research', Review of Economic Studies 33 (1966), pp. 133-145.

Quah, D.T. and Keely, L.C., 'Technology in Growth', CEP Discussion Paper 391 (1998).

Romer, P.M., 'Growth Based on Increasing Returns Due to Specialization', American Economic Review 77 (1987), pp. 56-62. 102. ,'Endogenous Technological Change', Journal of Political Economy 98 (1990), pp. 71-

Schneider, J. and Ziesemer, T., 'What's New and What's Old in New Growth Theory: Endogenous Technology, Microfoundation and Growth Rate Predictions', METEOR Research Paper 96/001 (1996).

Shaw, E.S., Financial Deepening in Economic Development, Oxford University Press, New York, 1973.

Shell, K., 'A Model of Innovative Activity and Capital Accumulation'. In: Shell, K. (ed.), Essays on the Theory of Optimal Economic Growth, MIT Press, Cambridge, 1967, pp. 67-85.

Soete, L., 'Uncertainty and Technological Change: Discussion'. In: Fuhrer, J.C. and Sneddon Little, J. (ed.), Technology and Growth: Conference Proceedings, Federal Reserve Bank of Boston, Boston, 1996, pp. 119-125.

Solow, R.M., 'A Contribution to the Theory of Economic Growth', Quarterly Journal of Economics 70 (1956), pp. 65-94.

Uzawa, H., 'Optimum Technical Change in an Aggregate Model of Economic Growth', International Economic Review 6 (1965), pp. 18-31.

Young, A., 'Growth without Scale Effects', Journal of Political Economy 106 (1998), pp. 4163. 